\title{
Tytuły w polskojęzycznych opisach przypadków medycznych - wstęp do badań
}

Titles of medical case reports in Polish - a preliminary study

\author{
Magda ŻELAZOWSKA-SOBCZYK \\ Uniwersytet Warszawski/ University of Warsaw \\ E-mail: magda.zelazowska@student.uw.edu.pl
}

\section{Magdalena ZABIELSKA}

Uniwersytet im. Adama Mickiewicza/ A. Mickiewicz University

E-mail: mzabielska@wa.amu.edu.pl

\begin{abstract}
While titles in scientific journals in general have attracted considerable interest, titles in medical research seem not to have been examined quite extensively. In these few studies, attention has been paid primarily to the form and length of titles as well as to their content. What is also emphasised is the need for discussion and further research on the topic in order to establish consistent guidelines regarding the formulation of clear and precise titles, which would aid journal editors, authors and readers. This paper constitutes an attempt to examine practices of formulating titles in medical case reports in Polish, following the study of F. Salager-Meyer et al. (2013a), in which title length, structure and content were considered as well.
\end{abstract}

Keywords: title, research article, case report, Polish, English

\section{Wstęp}

Znaczenie tytułu nadawanego artykułowi naukowemu jest zdecydowanie większe niż miejsce, jakie zajmuje on w publikacji proporcjonalnie do całego tekstu. Tytuły publikacji fachowych, standardowe pole eksploracji dla elektronicznych narzędzi wyszukiwania, to również sposób zwrócenia uwagi na naukowe dokonania badacza, za którym mogą iść tak bardzo pożądane cytowania, przyczyniające się do budowania pozycji naukowej badacza. W tym kontekście tytuły zyskują nowe znaczenie. Pomimo dużego zainteresowania formułowaniem tytułów w artykułach naukowych wydaje się, iż tematyka ta w kontekście medycznym nie była dotychczas podejmowana przez wielu badaczy. W tych nielicznych badaniach powtarzające się analizowane wątki to zarówno forma i długość tytułów, jak i ich treść. Podkreśla się także potrzebę dyskusji i kolejnych badań, które posłużyłyby wypracowaniu jednolitych zasad tworzenia jasnych i precyzyjnych tytułów, z korzyścią dla redaktorów czasopism, autorów i czytelników. Niniejsza praca to próba zbadania praktyk formułowania tytułów w polskojęzycznych medycznych opisach przypadku. Autorki dokonały również przeglądu literatury dotyczącej tytułów, zarówno ogólnie w artykułach naukowych oraz w kontekście medycznym, w obydwu przypadkach w odniesieniu do ich formy, 
funkcji, klasyfikacji, aspektów problematycznych, jak i zaleceń dotyczących ich formułowania. Następnie przeprowadzono badanie analogiczne do F. Salager-Meyer, M. Ángeles Alcaraz Ariza i M.L. Briceño (2013), w którym również wzięto pod uwagę długość, strukturę oraz treść badanych tytułów. Dane stanowiły tu tytuły 640 opisów przypadków z 16 polskich specjalistycznych czasopism medycznych (po jednym z głównych dziedzin medycyny za lata 2012-2016).

\section{Przegląd literatury dotyczącej tytułów w publikacjach naukowych}

O ile tematyka formułowania tytułów w tekście naukowym z dziedziny medycyny, również na gruncie polskim, dotychczas nie cieszyła się dużym zainteresowaniem badaczy, o tyle w kontekście tekstu naukowego ogólnie w badaniach anglojęzycznych mówi się już o tzw. „titleology” (A. Baicchi 2003 w V. Soler 2011: 124), czyli swego rodzaju działu badań poświęconemu tytułom. Odnosząc się do funkcji tytułów, badacze zwracają uwagę na szereg aspektów: są one znaczącym elementem w publikacji (J. Swales 1990), pierwszym punktem styczności czytelnika z tekstem (P.F. Kotur 2002: 23, S. Brkic/ M. Vucenovic/ Z. Dokic 2003: 207), zapraszającym do lektury (K.R. Pereira 2016: 394), a także elementem organizującym następującą po nim treść (J. Hartley/ L. Betts 2007: 2335). Dodatkowo są one elementem krytycznym dla funkcjonowania narzędzi wyszukiwania w Internecie (J.C. Hays 2010: 101). Obserwacje te odnoszą się zatem nie tylko do oczywistej informacyjnej funkcji tytułów, także w dobie Internetu, ale również do funkcji spajającej całość publikacji i świadczącej o jego spójności, używając metafory M.A.K. Halliday'a (1970), pewnego rodzaju wieszaka, na którym zawieszony jest komunikat tekstu (M.A.K. Halliday użył jej w kontekście tzw. perspektywy pragmatycznej obieranej w tekście).

Dostępna literatura dotycząca tytułów fachowych publikacji naukowych podejmuje tematykę ich formy i funkcji (na podstawie różnego rodzaju danych) oraz klasyfikacji, które z kolei mają służyć tworzeniu zaleceń ich formułowania, jak również omawia aspekty problematyczne, tj. kiedy owe zalecenia nie są stosowane.

\subsection{Forma i klasyfikacje}

W odniesieniu do klasyfikacji, F. Salager-Meyer i M. Alcaraz Ariza (2013a: 264) proponują zestaw kategorii tytułów opartych na formie i funkcji:

- czasownikowe vs. rzeczownikowe; czasownikowe to tytuły „informacyjne, twierdzące" (R. Smith 2000: 915, R.A. Rosner 1990: 108), zawierające czasownik aktywny wraz z pełnym zdaniem, przekazującym zazwyczaj wyniki lub konkluzje badania, np. „Fibrates help lower LDL”; tytuły rzeczownikowe, ,wskazujące”, nie zwierające odmienionego czasownika, np. „Help of fibrates in LDL lowering";

- tytuly „tematyczne”, np. „Papilliferous carcinoma of the thyroid gland”;

- tytuły przyciągające uwagę, tj. „Wired bladder in a cordless era”;

- tytuły-pytania, np. „Seizure or syncope? A channelopathy with cardiac and cerebral manifestation"; 
- tytuły wymieniające procedury badawcze, tj. zawierające informacje o celach, metodach i/ lub wynikach, np. „Case of recovery from taking a large quantity of tincture of opium".

Nieco bardziej szczegółową kategoryzację proponuje J. Hartley (2007a: 96-98). R.A. Goodman, S.B. Thacker i P.Z. Siegel (2001) z kolei prezentują klasyfikację ze względu na treść. P.Z. Siegel et al. (2006), analizując artykuły z recenzowanych czasopism medycznych pokazują, iż na 420 tytułów $40 \%$ tyczyło się tematu, $33 \%$ opisywało metody, $18 \%$ wyniki a dane tylko $2 \%$. Autorzy dodają również, iż nieliczne czasopisma wymagają $\mathrm{w}$ tytule informacji o metodzie (BMJ, The Lancet online, $\mathrm{w}$ F. Salager-Meyer i M. Ángeles Alcaraz Ariza 2013a).

\subsection{Zalecenia w kwestii formułowania tytułów}

Mając na uwadze typy tytułów, inne badania formułują swego rodzaju zalecenia co do ich zawartości, oraz, przynajmniej częściowo, formy. Większość dostępnych publikacji wskazuje na konieczność precyzyjności przekazu w tytule. Innymi słowy, tytuł powinien być: dokładny, precyzyjny (M. Zeiger 1991, S. Brkic/ M. Vucenovic/ Z. Dokic 2003: 207), jednoznaczny (M. Zeiger 1991, C. Mack 2012, R.A. Rison/ M.R. Kidd/ C.A. Koch 2013), konkretny, szczegółowy (M. Zeiger 1991, S. Brkic/ M. Vucenovic/ Z. Dokic 2003: 207), wyczerpujący (M. Zeiger 1991), a co za tym idzie, pod względem formy bez niejasnych skrótów, skrótowców (P.F. Kotur 2002: 23, S. Brkic/ M. Vucenovic/ Z. Dokic 2003: 207, wytyczne AMA - American Medical Association w J.C. Hays 2010: 102, C. Mack 2012, K.R. Pereira 2016) oraz bez terminologii technicznej czy żargonu (S. Brkic/ M. Vucenovic/ Z. Dokic 2003: 207, C. Mack 2012, A.Y. Gasparyan i in. 2011: 1411). Po drugie, tytuł powinien być opisowy (R.A. Rison/ M.R. Kidd/ C.A. Koch 2013), ale nie deklaratywny (wytyczne NEJM - New England Journal of Medicine w S. Brkic/ M. Vucenovic/ Z. Dokic 2003: 207), wskazujący na konkretną treść i bogaty w informacje (również o wynikach) (S. Brkic/ M. Vucenovic/ Z. Dokic 2003: 207). Po trzecie powinien być zwięzty (M. Zeiger 1991, wytyczne $N E J M$ w S. Brkic/ M. Vucenovic/ Z. Dokic 2003: 207, P.F. Kotur 2002: 23, wytyczne $A M A$ w J.C. Hays 2010: 102, C. Mack 2012, A.Y. Gasparyan i in. 2011: 1411, K.R. Pereira 2016). Kolejne zalecenia prezentowane w publikacjach odwołują się do funkcji, jakie powinny pełnić tytuły, będąc pochodną ich treści i formy. Powinny one zawierać główną myśl/ temat pracy (M. Zeiger 1991, P.F. Kotur 2002: 23, S. Brkic/ M. Vucenovic/ Z. Dokic 2003: 207, G. Lewison/ J. Hartley 2005: 341, J. Hartley 2007b: 148, J.C. Hays 2010, C. Mack 2012, K.R. Pereira 2016), ale nie wyniki (C. Mack 2012, por. S. Brkic/ M. Vucenovic/ Z. Dokic 2003: 207). Ich zadaniem powinno być również zwrócenie uwagi czytelnika (P.F. Kotur 2002: 23, S. Brkic/ M. Vucenovic/ Z. Dokic 2003: 207, J. Hartley 2005, G. Lewison/ J. Hartley 2005: 341, J. Hartley 2007b: 148, C. Ortega-Loubon/ R. Correa-Márquez 2014: 91).

\subsection{Problemy towarzyszące formułowaniu tytułów}

Kolejnym zagadnieniem podejmowanym przez badaczy zajmujących się tytułami są problemy związane $\mathrm{z}$ ich formułowaniem i efektem uzyskanym na skutek zastosowa- 
nych środków językowych. W tym kontekście można wspomnieć tzw. „titular colonicity" (ang. colon - średnik) - tytuły tzw. 'zawieszone' na skutek zastosowania średnika a później podtytułu, który stanowi, według badaczy, „epidemię” wśród tekstów naukowych (J. Hartley 2005), polegającą na coraz dłuższych tytułach. Dlatego też szereg publikacji odradza używanie podtytułów (S. Brkic/ M. Vucenovic/ Z. Dokic 2003: 207), jak również dodawania informacji o typie publikacji np. tj.: ,przegląd badań”, „opis przypadku” itp. (A.Y. Gasparyan i in. 2011: 1411). B. Budgell (2008: 200) oraz R.A. Agha i in. (2016) z kolei proponują umieszczanie nazwy gatunku w tytule. W kwestii formy zaleca się również stosowanie nominalizacji i używanie rzeczowników odczasownikowych oraz podkreślenie obecność aktora, agensa (J.M. Williams 2009), inaczej prezentowana przez autora procedura może być niejasna (J.C. Hays 2010: 101). Kontynuując wątek formy tytułu, szereg badań potwierdza zależność między stosowaniem dwukropka a zwiększoną cytowalnością. Wynik ten można thumaczyć zwiększonymi możliwościami wyszukania artykułu (J. Hartley 2007b: 148, S.J. Jacques/ N.J. Sebire 2010 w A.Y. Gasparyan i in. 2011: 1411). Owego poglądu nie podziela J.C. Hays (2010).

\subsection{Korelacje, ujęcia, języki i dyscypliny}

Poruszając się nadal w tematyce literatury dotyczącej tytułów, bez uwzględniania jednak wskazówek co do ich formułowania, istnieje szereg badań wskazujących na pewne korelacje lub zastosowanie konkretnych ujęć badawczych. S.J. Jacques i N.J. Sebire (2010) zbadali zależność między pewnymi cechami tytułów a ich cytowalnością, konkludując, iż dłuższe tytuły są bardziej szczegółowe i zawierają słowa klucze, akronimy, dwie frazy lub dwa zdania.

W kontekście ujęć badawczych, wyżej wspomniane badania F. Salager-Meyer i M. Alcaraz Ariza (2013a, b) oraz F. Salager-Meyer, M. Ángeles Alcaraz Ariza i M.L. Briceño (2013) stanowią przykłady zastosowania ujęcia historycznego. Autorki wykazały, iż generalnie brak wyraźnych twierdzeń w tytułach opisów przypadku jest konsekwencją ich treści, tj. opisów jednostkowych przypadków (F. Salager-Meyer/ M. Alcaraz Ariza 2013a). Wskazały także na kierunek rozwoju tytułów opisów przypadku, tj. zwiększającą się długość, złożoność składniową, bogactwo semantyczne oraz różnorodność typów (F. Salager-Meyer/ M. Alcaraz Ariza 2013b).

Odrębną grupę badań stanowią porównania tytułów w odniesieniu do różnych dyscyplin lub języków. I. Busch-Lauer (2000) wykazała, iż tytuły w języku angielskim są proste a w języku niemieckim bardziej złożone, zawierające podtytuł; tytuły publikacji medycznych są dłuższe, precyzyjne i bogate w informacje, w publikacjach językoznawczych z kolei krótsze, niejasne, abstrakcyjne, chwytliwe oraz odzwierciedlające indywidualny styl (I. Busch-Lauer 2000). G. Lewison i J. Hartley (2005) wskazują na fakt, iż liczba tytułów z dwukropkiem zwiększyła się, jednak liczby te są różne dla poszczególnych dziedzin. Średnia liczba słów w tytułach ogólnie to 15.48 w medycynie, $14.98 \mathrm{w}$ naukach przyrodniczych, $10.89 \mathrm{w}$ naukach społecznych i 7.98 w językoznawstwie (V. Soler 2007). W kontekście medycznym wyłącznie, N.W. Goodman (2000) zbadał czasowniki aktywne w klinicznych opisach przypadku i stwierdził, iż tytuły mogą być wskazujące lub informujące, odpowiednio „Newbetalol in the 
treatment of tachycardias” lub „Newbetalol prevents tachycardias” (por. wyżej wspomnianą klasyfikację F. Salager-Meyer i M. Alcaraz Ariza 2013a). Nadmienił również, iż tytuły informujące stają się coraz bardziej popularne. W medycznych artykułach naukowych z kolei średnia długość tytułu to 10.9 słów, 99\% tytułów zawiera grupy rzeczownikowe, 98\% jest bez podtytułów, 68\% z użyciem fraz przyimkowych opisujących rzeczownik (Y. Wang/Y. Bai 2007). Warto też wskazać publikacje dotyczące formy tekstów medycznych z uwzględnieniem kwestii tytułów: P.F. Kotur (2002), S. Brkic/ M. Vucenovic/ Z. Dokic (2003), G. Lewison/ J. Hartley (2005), J. Hartley (2007b), A.Y. Gasparyan i in. (2011) oraz K.R. Pereira (2016).

Ostatni dział literatury dotyczącej tytułów artykułów medycznych jest adresowany do rodzimych użytkowników języka chińskiego (X.J. An/ R.Z. Zhang 1994; Y.Z. Xu 1996; J.W. Ma/ X.W. Wang 1997; J.Q. Jiang 2000; P. Duan/ W.P. Gu 2002; H.M. Leng/ J.X. Guo 2003; Z.L. Xue 2003; S.L. Yao/ D.W. Wu/ S.H. Zhang 2004).

\section{Tytuły w polskojęzycznych opisach przypadku - badanie}

\subsection{Etapy analizy materiału badawczego}

Na wstępie warto podkreślić, iż przeprowadzone badanie jest w pewnym stopniu replikacją badań F. Salager-Meyer, M. Ángeles Alcaraz Ariza i M.L. Briceño (2013), jednak autorki uzupełniły je o kilka własnych elementów oraz kryteriów analizy w celu wzbogacenia wyników i uzyskania szerszego spektrum zastosowania ich w praktyce lub późniejszego uzupełnienia badania.

Analiza materiału badawczego podzielona została na kilka etapów. Pierwszym z nich był przegląd listy czasopism punktowanych Ministerstwa Nauki i Szkolnictwa Wyższego $^{1}$ (dalej MNiSW) oraz zasobów internetowych w celu znalezienia jednego multidyscylinarnego czasopisma, publikującego artykuły z różnych dziedzin medycyny (np. w języku angielskim jest to British Medical Journal lub The Lancet itp.). Na rynku polskojęzycznym takie czasopismo nie jest dostępne, gdyż wszystkie periodyki naukowe są powiązane z poszczególnymi dziedzinami medycyny. Kolejnym krokiem było wyszukiwanie czasopism naukowych według dziedziny poprzez wyszukiwarkę ARIANTA - Naukowe i branżowe polskie czasopisma elektroniczne. Podstawowym kryterium wyszukiwania była punktacja MNiSW, nie mniejsza niż 5 punktów. Z listy czasopism wybierano te, które (1) posiadały wskaźnik MNiSW powyżej 5, (2) publikowane były w języku polskim, (3) posiadały dostęp internetowy do zasobów za lata 2012-2016, (4) publikowały opisy przypadków, przynajmniej po jednym w każdym roku. Z tak wyselekcjonowanej listy dalej wybrano czasopisma z najwyższą liczbą punktów MNiSW za rok 2016. Przy selekcji czasopism pojawiły się trudności w wyborze odpowiedniego czasopisma $\mathrm{z}$ danej dziedziny: (1) brak czasopisma w języku polskim (na podstawie analizy wydawanych numerów, zauważyć można, iż wiele czasopism polskojęzycznych, publikujących artykuły w języku polskim, w ciągu kilku ostatnich lat zmieniło profil publikacji, nastawiając się na język angielski,

\footnotetext{
${ }^{1}$ http://www.nauka.gov.pl/ujednolicony-wykaz-czasopism-naukowych/wykaz-czasopism-naukowych-zawierajacy-historie-czasopisma-z-publikowanych-wykazow-za-lata-20132016.html (dostęp: 12.02.2017).
} 
zyskując tym samym większy prestiż i w niektórych przypadkach nawet wskaźnik Impact Factor), (2) czasopisma posiadały niższą punktację MNiSW niż przyjęty wskaźnik 5 punktów, dlatego wybór czasopism był ograniczony, (3) czasopisma powtarzały się przy wyborze różnych dziedzin, np. ginekologia i położnictwo, ze względu na przybliżony profil tematyczny, (4) czasopisma nie posiadały lub posiadały ograniczony dostęp do zasobów elektronicznych, tj. tylko do wybranych artykułów. W związku z obszerną liczbą czasopism znajdujących się w bazie ARIANTA i na liście B czasopism punktowanych MNiSW, zdecydowano o wyborze czasopism tylko z poszczególnych dziedzin, które spełniały powyższe kryteria. Wyboru dziedzin dokonano na podstawie listy zaproponowanej przez wyszukiwarkę ARIANTA oraz wykazu specjalności lekarskich i lekarsko-dentystycznych, opracowanego przez Ministerstwo Zdrowia $^{2}$. Na podstawie obszernej analizy materiału i zasobów elektronicznych wybrano 16 czasopism w języku polskim z takich dziedzin jak: anestezjologia, chirurgia, choroby układu krążenia (kardiologia), choroby układu trawienia, choroby zakaźne, dermatologia, endokrynologia, ginekologia, laryngologia, neurologia, okulistyka, onkologia, pediatria i psychiatria. Autorki są w pełni świadome, jakie ograniczenia niesie za sobą niniejsze badanie, zawężając materiał tylko do wybranych, a nie wszystkich głównych specjalności w medycynie, oraz skupiając się tylko na kilkudziesięciu czasopismach z długiej listy wszystkich periodyków. Tym samym autorki podkreślają, iż zebrany materiał badawczy nie jest całkowicie reprezentatywny dla całej medycyny i przedstawia tylko wybraną próbkę tekstów. Otwiera to jednak pole do dalszych badań na większym korpusie tekstów medycznych, a w szczególności ich mikrogatunku - opisach przypadków.

Kolejnym etapem po wyborze czasopism był przegląd zasobów internetowych (stron internetowych poszczególnych czasopism) i wybranie tytułów wszystkich opisów przypadków w języku polskim, opublikowanych w każdym numerze czasopisma w latach 2012-2016. W tym miejscu ograniczeniem badania była nieregularność publikowania opisów przypadków: (1) niekiedy nie były one publikowane w każdym numerze lub nawet w danym roku, (2) w zależności od czasopisma publikowana była różna liczba opisów przypadków w danym numerze i roku (widać znaczne różnice pomiędzy niektórymi czasopismami, np. Klinika Oczna - 69 opisów w okresie 5 lat, podczas gdy w Neurologii Dziecięcej opublikowano tylko 13).

Po zgromadzeniu wszystkich tytułów opisów przypadków z 16 wybranych czasopism dokonano ich analizy. Łącznie przeanalizowano tytuły 640 opisów przypadków w języku polskim, opublikowanych w latach 2012-2016. Analiza przebiegała dwuetapowo. Pierwszym etapem była analiza ilościowa z wykorzystaniem wcześniej przygotowanego korpusu ze zgromadzonych tytułów przy pomocy programu AntConc. Podczas tej analizy wyszukano ilościowe parametry badanych tekstów: liczbę i kontekst (miejsce) występowania fraz „opis przypadku”, „,studium przypadku”, ,analiza

\footnotetext{
${ }^{2}$ http://www2.mz.gov.pl/wwwfiles/ma_struktura/docs/zalaczniki14_rozpo_23052006.pdf (dostęp: 07.04.2017).
} 
przypadku”, ,prezentacja przypadku” oraz inne warianty fraz ze słowem ,przypadek"3 i „trudności diagnostyczne”, które to wydzielono na podstawie wcześniejszej obserwacji tekstów (widać wyraźną frekwencję wstępowania); częstość zastosowania dwukropka, przecinka lub kropki oraz frekwencję użycia myślnika, który to jest dominującym znakiem w opisach przypadków. Skupiono się także na jednym dodatkowym aspekcie pozagramatycznym - wyszukaniu frazy ,pacjent”, ,pacjentka” lub „przypadek” - określające podmiot opisu - osobę. Drugim etapem badania była analiza jakościowa tytułów opisów przypadków dokonana ręcznie przy pomocy tabeli w programie Excel. Przy badaniu materiału zwracano uwagę na: (1) rodzaj tytułu - czy jest on tematyczny, pytający lub przyciągający uwagę, (2) co jest głównym przedmiotem badania (czy podana jest metoda leczenia lub procedura operacyjna, czy opisane jest tylko schorzenie), (3) czy są to tytuły czasownikowe czy rzeczownikowe, (4) czy tytuły są proste czy złożone (czy zawierają złożone rzeczowniki i przymiotniki), (5) jak długie są te tytuły (liczba wyrazów), (6) ile tytułów wskazuje na wiek lub inną charakterystykę pacjenta, (7) ile na rzadkość badania (np. ,rzadki”, „nietypowy”), (8) czy tytuły zawierają eponimy, oraz (9) czy są inne dodatkowe cechy, wyróżniające dany tytuł.

Poniżej przedstawione zostaną wyniki uzyskane w drodze analizy ilościowej i jakościowej korpusu tekstów (tytułów opisów przypadków).

\subsection{Wyniki}

Pierwszym kryterium, na które zwrócono uwagę w badaniu była długość tytułów. Średnia długość tytułów wyniosła 11 wyrazów. Najdłuższy tytuł zawierał 28 słów, a najkrótszy - 2. W badaniu F. Salager-Meyer, M. Ángeles Alcaraz Ariza i M.L. Briceño (2013), w tytułach anglojęzycznych średnia wartość tytułów wynosiła 9,7 - wynika $\mathrm{z}$ tego więc, że tytuły polskich opisów były dłuższe. Poniżej przedstawione zostały przykłady obrazujące ww. zależności.

- $\quad$ Czy zawsze unikać stymulacji komorowej? Skuteczność sekwencyjnej stymulacji dwujamowej $w$ redukcji istotnego gradientu $w$ drodze odptywu lewej komory i objawów klinicznych u chorego z kardiomiopatia przerostową zawężająca.. (Kardiologia Polska)

- $\quad$ Liszaj kolczysty. (Przegląd Dermatologiczny)

Kolejną analizowaną cechą był rodzaj tytułów. W korpusie tekstów, w odróżnieniu od badania F. Salager-Meyer, M. Ángeles Alcaraz Ariza i M.L. Briceño (2013), nie występowały tytuły czasownikowe, jednak posiadały one różnorodne konstrukcje zastępcze, m.in.:

- Mięśniaki gładkokomórkowe skóry imitujące keloidy. (Dermatologia Polska)

\footnotetext{
${ }^{3}$ Ze względu na ograniczenia programu AntConc, który wyszukuje dokładne frazy, wyszukano także formy ,przypadku” i ,przypadków”, co dało rzetelniejsze wyniki w postaci innych fraz, np. ,opis dwóch przypadków”.
} 
- $\quad$ Zespót wad wrodzonych ze złożona wada serca i zaburzeniami krzepnięcia sugerujący spektrum oczno-uszno-kręgowe - opis przypadku. (Pediatria Polska)

Wszystkie analizowane tytuły były rzeczownikowe oraz tematyczne, np.:

- $\quad$ Duża objawowa torbiel okołoosierdziowa. (Kardiologia Polska)

- Zespół Bartha - opis przypadku. (Neurologia Dziecięca)

- Zespót Goodpasture'a wyzwaniem diagnostycznym i terapeutycznym dla lekarza kardiologa. (Folia Cardiologica)

- $\quad$ Rak z komórek Merkla. (Klinika Oczna)

Występowały również tytuły dotyczące procedury badawczej, w tym zastosowanego leczenia operacyjnego i farmaceutycznego oraz pozytywnych i negatywnych wyników leczenia itp., m.in.:

- Implantacja stentu do lewej tętnicy plucnej monitorowana angiografia rotacyjna z trójwymiarowa rekonstrukcją. (Folia Cardiologica) ${ }^{4}$

- Znieczulenie ogólne do cholecystektomii laparoskopowej w trybie pilnym u pacjenta obciążonego przewlekta niezdiagnozowana przed laty pourazowa przepuklina przeponowa - opis przypadku. (Anestezjologia i Ratownictwo)

- Cystektomia z wytworzeniem zastepczego pęcherza jelitowego u pacjenta z ektopia nerki prawej. (Chirurgia Polska)

- $\quad$ Ciężkie zatrucie salicylanami u 7-letniej dziewczynki leczonej z powodu świerzbu maścią salicylowa. (Pediatria Polska)

- $\quad$ Zator tętnicy krezkowej górnej skutecznie leczony metodami wewnątrznaczyniowymi - opis przypadku. (Chirurgia Polska)

- $\quad$ Nieprawidłowe odejście gałęzi prawej tętnicy ptucnej od aorty zstepujacej. Opis pomyślnego przebiegu leczenia. (Kardiologia Polska)

- $\quad$ Ziarniniak Wegenera - trafna diagnostyka i szybkie rozpoznanie w Oddziale Laryngologii Szpitala Powiatowego. (Otorynolaryngologia)

- $\quad$ Opryszczkowate zapalenie skóry btędnie rozpoznane i leczone jako grzybica skóry gladkiej. (Przegląd Dermatologiczny)

- $\quad$ Skuteczne leczenie zapalenia siatkówki i nerwu wzrokowego pozagatkowym podaniem gancyklowiru u dziecka po autologicznym przeszczepie szpiku z zastosowaniem treosulfanu. (Klinika Oczna)

Dwoma ostatnimi rodzajami tytułów występującymi w medycznych opisach przypadków w języku polskim były te przyciągające uwagę czytelnika (a) i tytuły w formie pytania (b). Poniżej przedstawiono ich przykłady:

(a)

- $\quad$ Padaczka arytmiczna, czyli zaskakująca historia pewnej padaczki. (Kardiologia Polska)

- Kiedy znika pót twarzy... - zespół Parry'ego-Romberga, opis przypadku. (Neurologia Polska)

- Nastolatek traci przytomność na ulicy. (Folia Cardiologica)

${ }^{4} \mathrm{~W}$ tym przypadku cały tytuł jest opisem procedury badawczej. 
- $\quad$ Erythema ab igne - jako efekt uboczny pracy w kwiaciarni-opis przypadku i przegląd literatury. (Przegląd Kardiologiczny)

- Dowody, preferencje, rekomendacje. Manowce medycyny faktów - prezentacja przypadku chorego na raka gruczolowego pluca. (Nowotwory)

- Kardiomiopatia restrykcyjna - historia ze szczesśliwym zakończeniem. (Pediatria Polska)

(b)

- $\quad$ Kwasica mleczanowa z pH<6,8-zatrucie alkoholem niespożywczym czy kwasica towarzyszaca leczeniu metformina? Opis przypadku. (Anestezjologia i Ratownictwo)

- Dermatomyositis - zespót paraneoplastyczny czerniaka złośliwego czy przypadkowe wspótistnienie? (Przegląd Dermatologiczny)

- $\quad$ Szczepić czy nie szczepić dzieci przeciw pneumokokom? - opis kilku przypadków inwazyjnej choroby pneumokokowej (IChP). (Pediatria Polska)

W tytułach zazwyczaj określany jest także narząd objęty chorobą, np.:

- Zaciskajace zapalenie osierdzia jako powikłanie wirusowej infekcji dróg oddechowych. (Kardiologia Polska)

- Zaburzenia funkcji przysadki i podwzgórza w wyniku późno rozpoznanego wodogłowia u 7-letniego chtopca - opis przypadku. (Endokrynologia Pediatryczna)

- Cewkowo-śródmiąższowe zapalenie nerek i błony naczyniowej - opis przypadku. (Klinika Oczna)

- $\quad$ Równoczesne przerzuty raka nerki do trzustki i tarczycy - opis przypadku i przegląd piśmiennictwa. (Nowotwory)

W tytułach polskojęzycznych, oprócz określenia procedury badawczej i wyniku leczenia (jak powyżej), pojawia się także wyjaśnienie pojęcia poprzez np. podanie innej polskiej lub obcojęzycznej nazwy:

- $\quad$ Problemy kardiologiczne u dziecka z zespołem monosomii 5p, zwanym zespołem kociego płaczu (cridu chat syndrome). (Pediatria Polska)

- $\quad$ Sudden unexplained nocturnal death syndrome (SUNDS), czyli zespót Brugadów. (Folia Cardiologica)

Warto także przyjrzeć się najczęściej występującym w tytułach jednostkom. Jak wynika z listy frekwencyjnej wygenerowanej z korpusu tekstów, stworzonego z 640 tytułów opisów przypadków, najczęściej występującymi, oprócz przyimków, słowami są: „,opis”, „przypadku”/ „przypadków”, ,zespół”/ ,zespołu”, ,,przebieg”, ,przegląd”, „,piśmiennictwa”, „,zapalenie”, „,pacjenta”/ „pacjentki”, „letniej”/ „letniego”, „trudności”, „dziewczynki”/ „chłopca”, ,chorego”/ „chorej” itp. W związku z tym zbadano kolokacje i liczbę występowania najczęściej pojawiających się w korpusie jednostek i uzyskano wyniki przedstawione w dalszej części pracy. 
Najczęściej pojawiającą się frazą jest „opis przypadku”. Analiza ilościowa fraz „przypadku” $\mathrm{i}$,przypadków” pokazuje, iż wyrażenia „opis przypadku”/ przypadków”, ,analiza przypadku/ przypadków”, „studium przypadku/ przypadków”, ,prezentacja przypadku" wystapiły w 316 tytułach, co stanowi prawie $50 \%$ wszystkich badanych tytułów $(49,38 \%)$. Wyrażenie „opis przypadku” pojawia się na końcu tytułu po myślniku (c) (poniżej), ewentualnie po kropce (d), rzadko po dwukropku (e), w jednym artykule w nawiasie na końcu po tytule (f). W odróżnieniu od badania F. Salager-Meyer, M. Ángeles Alcaraz Ariza i M.L. Briceño (2013), w korpusie polskojęzycznym frazę tę rzadziej spotyka się na początku tytułu (g). „Opis przypadku” czasami zastępowany jest wyrażeniami „studium przypadku”, ,analiza przypadku”, „przedstawienie przypadku”, w jednym tytule „opis pacjenta” (h) itp. Warto tu także wspomnieć, iż „studium przypadków” stosowane jest częściej w opisach przypadków w psychologii i psychiatrii (i), np. w czasopiśmie Psychiatria Polska. Dodatkowo warto zauważyć, iż występowały tu także inne formy (j). Poniżej przedstawione zostały przykładowe tytuły, w których występują ww. jednostki.

(c)

- Choroba von Willebranda z punktu widzenia potożnika - opis przypadków. (Ginekologia i Położnictwo)

- Jednostronny obrzęk tarczy nerwu wzrokowego jako pierwszy objaw toksoplazmozy ocznej - analiza przypadku. (Klinika Oczna)

- Wykorzystanie wirtualnej bronchoskopii w nowoczesnej diagnostyce dróg oddechowych u dzieci - opis wybranych przypadków. (Pediatria Polska)

(d)

- Limbiczne zapalenie mózgu z obecnościa przeciwcial anty-LGI1 u 3-letniego chlopca. Przedstawienie przypadku. (Neurologia Dziecięca)

(e)

- Choroba Kikuchi i Fujimoto: opis dwóch nowych polskich przypadków i aktualny przeglad piśmiennictwa. (Acta Haematologia Polonica)

(f)

- $\quad$ Alergia czy zespót hyper-IgE - trudności diagnostyczne (opis przypadku). (Pediatria Polska)

(g)

- Opis przypadku 15-letniej dziewczynki z zespolem Aperta. (Neurologia Polska)

- Opis przypadku olbrzymiej torbieli watroby zaopatrzonej sposobem laparoskopowym. (Gastroenterologia Polska)

(h)

- Analiza przypadków obustronnego czerniaka blony naczyniowej w materiale wtasnym i przegląd piśmiennictwa. (Klinika Oczna)

\footnotetext{
${ }^{5}$ Uzyskano 265 wyników wyszukiwania, które dotyczą fraz ze słowem ,przypadku”, jednakże 3 wyszukiwania nie odnoszą się do frazy „opis przypadku” lub fraz pochodnych, ale do określenia konkretnego przypadku, czyli pacjenta - ,w przypadku bardzo trudnej intubacji”, „,metody postępowania w ich przypadku” oraz ,postępowanie w przypadku”.
} 
- $\quad$ Subiektywne i obiektywne zjawiska akustyczne w przebiegu czynnościowych zaburzeń układu ruchowego narządu żucia - analiza przypadku. (Otorynolaryngologia)

- $\quad$ Nagłe zatrzymanie krążenia u młodej osoby dorostej - studium przypadku. (Folia Cardiologica)

- $\quad$ Polipoidalnawaskulopatia naczyniówkowa z samoistna regresja zmian poddołkowych - opis pacjenta. (Klinika Oczna)

(i)

- Zaburzenia emocjonalne u pacjentów z uszkodzeniem móżdżku - studium przypadków. (Psychiatria Polska)

(j)

- Przypadek równoczesnego występowania wrodzonego rozwarstwienia siatkówki sprzężonego z chromosomem $X-w$ jednym oku, i błony podsiatkówkowej-w drugim oku, u dwóch członków tej samej rodziny. (Klinika Oczna)

- Heterogenność zespołu Guillaina-Barrégo na przykładzie opisu przypadków. (Pediatria Polska)

Przechodząc do dalszych rozważań, warto zauważyć, iż oprócz wyżej wymienionych wyrażeń, w tytułach medycznych opisów przypadków występują również inne jednostki określające trudności diagnostyczne $(\mathrm{k})$, obserwacje własne autorów (1), typ pracy, np. przegląd dostępnego piśmiennictwa (m), wiek pacjenta (n) oraz rzadkość i nietypowość opisywanego schorzenia (o). Wspomniane tendencje mogą zobrazować poniższe przykłady.

(k)

- $\quad$ Atypowa postać zespolu tako-tsubo zwiazanego z migotaniem przedsionków w zespole Wolffa-Parkinsona-White'a powikłanego nagłym zatrzymaniem krażenia: trudności diagnostyczne. (Kardiologia Polska)

- Nawracajace zapalenie chrząstek - problem diagnostyczny. (Przegląd Dermatologiczny)

- $\quad$ Trudności $\boldsymbol{w}$ rozpoznaniu tyrozynemii typu 1 z perspektywy onkologa - opis przypadku. (Pediatria Polska)

- Trudna droga do rozpoznania otepienia z ciałami Lewy'ego. Opis przypadku. (Psychiatria Polska)

- $\quad$ Skrzepliny wewnatrzsercowe w zatorowości plucnej a priori niewysokiego ryzyka: dylematy terapeutyczne. (Kardiologia Polska)

- Dodatkowa masa na elektrodzie wewnątrzsercowej - wątpliwości diagnostyczne i wybór postepowania leczniczego. (Kardiologia Polska)

- Resekcja żoładka z nagtych wskazań z przezrozworowa resekcja przełyku: trudna decyzja podczas dyżuru. (Nowotwory)

- Trudny technicznie, ważny diagnostycznie - ekson ORF15 genu RPGR w zwyrodnieniu barwnikowym siatkówki. (Klinika Oczna)

(1)

- Dysplazja kampomeliczna i zespół odwrócenia ptci-sześcioletnia obserwacja. (Endokrynologia Pediatryczna)

- Wrodzony nowotwór łagodny nabłonka barwnikowego siatkówki typu hamartomadlugoterminowa obserwacja przypadku klinicznego. (Klinika Oczna) 
- $\quad$ Leczenie hybrydowe noworodka z przerwanym tukiem aorty i przeciwwskazaniami do krązenia pozaustrojowego: opis przypadku z uwzględnieniem 1,5-rocznej obserwacji. (Kardiologia Polska)

(m)

- Dacrocystorhinostomia w leczeniu niskiego zwężenia przewodu nosowo-łzowego opis przypadku i przegląd piśmiennictwa. (Otorynolaryngologia)

- $\quad$ Przepuklina Morgagniego. Przegląd piśmiennictwa w oparciu o opis przypadku. (Gastroenterologia Polska)

- $\quad$ Rzadko wystęujaca genodermatoza (acral peeling skin syndrome) - opis przypadku. Przegląd piśmiennictwa dotyczącego odmiany ograniczonej i uogólnionej. (Przegląd Dermatologiczny)

W przypadku przykładów w (k) (powyżej), warto tu dodać, że najczęściej stosowane są wyrażenia tj. „trudności diagnostyczne”, ,problem diagnostyczny”; ,dylematy terapeutyczne", "trudna droga w rozpoznaniu” itp. pojawiają się rzadko. Co się tyczy grupy przykładów (m) (powyżej), wyrażenia „przegląd piśmiennictwa” i podobne występują najczęściej po słowach „opis przypadku”. Zwykle pojawia się „przegląd piśmiennictwa”, rzadziej „przegląd literatury”. „Przegląd piśmiennictwa” łączy się z przymiotnikami, które określają jego typ: „systematyczny”, „krótki”, ,aktualny” itp. W jednym przypadku doprecyzowany jest zakres ,przeglądu literatury”.

Określenie wieku pacjenta występuje w 70 tytułach (tj. 11\%) (n), a ma to miejsce głównie w czasopismach pediatrycznych, m.in. Pediatria Polska. Najczęściej stosowane wyrażenie w tytułach przy określaniu wieku zawiera przyimek „u”, np. „u 2letniej dziewczynki”, „u 18-letniej ${ }^{6}$ chorej” itp.

(n)

- Zespót naczyniaków gumiastych u 2-letniej dziewczynki. (Neurologia Polska)

- Czteromiesięczne niemowle z zapaleniem mięśnia sercowego i zespołem Blanda, White'a i Garlanda - trudne rozpoznanie. (Pediatria Polska)

- Postać twardzinopodobna porfirii skórnej późnej u 64-letniej kobiety. (Przegląd Dermatologiczny)

- Pacjentka w wieku 63 lat z mnogimi przetokami między krążeniem wieńcowym i plucnym. (Kardiologia Polska)

W tym miejscu warto również wspomnieć o samym określeniu ,przypadku”, w rozumieniu pacjenta, będącego 'przedmiotem' opisu przypadku. Powyżej omówione zostało zagadnienie wieku, natomiast interesującym jest także sposób przedstawienia pacjenta. Stosowane są do tego takie wyrażenia jak (według frekwencji): ,pacjentka”/ "pacjentki”, ,pacjent”/ „pacjenta”, „chorego”/ „chorej”, ,dziewczynki”/ „chłopca”,

\footnotetext{
${ }^{6} \mathrm{~W}$ jednym z etapów analizy ilościowej uzyskano 4 wyniki wyszukiwania „letnia”, z czego 2 dotyczą obserwacji, a nie pacjentki, tj. „obserwacja dwuletnia” oraz „obserwacja 3-letnia”; i 35 wyników wyszukania „letniej”, jednak jeden wynik odnosi się do obserwacji, tj. „w obserwacji dwuletniej".

${ }^{7}$ Najczęściej w formach „u pacjenta”, „u chłopca” itd.
} 
„dziecka” oraz „kobiety”/ „mężczyzny” (o). Występują tu także inne, rzadziej stosowane określenia pacjenta $(\mathrm{p})$.

(o)

- Dlugotrwała pancytopenia po chemioterapii jako objaw demaskujacy chorobę Gauchera u pacjentki z rakiem pluca. (Acta Haematologica Polonica)

- Cukrzyca typu HNF1A MODY u 14-letniej dziewczynki z otytościa. (Pediatria Polska)

- $\quad$ Nabyty inhibitor czynnika VIII w przebiegu raka prostaty u 71-letniego mężczyzny - opis przypadku. (Acta Haematologica Polonica)

(p)

- Zachowawcze leczenie ciąży szyjkowej u pierworódki - opis przypadku. (Ginekologia i Położnictwo)

- Choroba Gravesa-Basedowa i myasthenia gravis u nastolatki - trudności diagnostyczne. (Endokrynologia Pediatryczna)

Warto tu również przytoczyć inne, niebezpośrednie określenia pacjenta, tj.:

- Zlośliwa osteopetroza niemowlęca - opis przypadku. (Pediatria Polska)

- $\quad$ Lagodne ostre dziecięce zapalenie mięśni - opis przypadku. (Pediatria Polska)

W poniższych przykładach $\mathrm{w}$ zauważyć możemy podkreślenie innowacyjności samego opisu, badania, nietypowości opisywanego schorzenia lub metody leczenia/ procedury badawczej.

- $\quad$ TRALI, nadal rzadko rozpoznawane, a jeszcze rzadziej zglaszane powikłanie poprzetoczeniowe - opis przypadku i przeglad piśmiennictwa. (Anestezjologia i Ratownictwo)

- Rzadka postać zespolu Lyncha z trzema synchronicznymi, o podobnym zaawansowaniu, ogniskami gruczolakoraka okrężnicy. (Chirurgia Polska)

- Pierwsza w Polsce implantacja pompy LENUS pro® u pacjenta z tętniczym nadciśnieniem ptucnym. (Kardiologia Polska)

- $\quad$ Typowe nietypowe objawy procesu infekcyjnego zwiazanego z układem stymulujacym. Znaczenie pozytonowej tomografii emisyjnej $w$ diagnostyce i ustaleniu postepowania. (Kardiologia Polska)

- Walka z powikłaniami elektroterapii - dlaczego wciaż jest taka trudna? Analiza dwóch zlożonych przypadków klinicznych. (Kardiologia Polska)

- $\quad$ Rzadki przypadek metalicznego ciała obcego w uchu środkowym-opis przypadku. (Otorynolaryngologia)

- $\quad$ Nowa metoda manualnej terapii krtani $w$ rehabilitacji zaburzeń czynnościowych głosu. (Otorynolaryngologia)

- $\quad$ Czteropłatkowa zastawka aortalna - rzadki wariant anatomiczny u 70-letniej pacjentki z objawami niewydolności serca. (Folia Cardiologica)

- Niezwykly przypadek wspótistnienia łuszczycy z liszajem plaskim. (Przegląd Dermatologiczny)

- Wrodzona wielohormonalna niedoczynność przysadki - choroba wciąż późno rozpoznawana. Opis przypadków. (Endokrynologia Polska) 
- Dziobata keratoliza - tagodna, czesto nierozpoznawana infekcyjna choroba skóry stóp. (Przegląd Dermatologiczny)

- $\quad$ Neurologiczne manifestacje niektórych wrodzonych zaburzeń metabolicznych - typowe sytuacje kliniczne. (Neurologia Dziecięca)

W tytułach pojawiały się także inne wyrażenia, których frekwencja nie jest wysoka. Określają one typ procedury badawczej/ etapy badania (tu: ,propozycja algorytmu...”), przyciągają uwagę czytelnika (,im więcej szukamy, tym więcej widzimy”), opisują zalecenia (,warto o niej pamiętać”), zwracają się do odbiorcy (,zanim rozpoznasz... zbadaj”) oraz przekazują opinie (,kontrowersje”).

- Dyskwalifikacja dawcy komórek krwiotwórczych w trakcie chemioterapii wysokodawkowanej u biorcy przygotowywanego do transplantacji: propozycja algorytmu postępowania ratunkowego. (Acta Haematologica Polonica)

- Ciężka dysfunkcja prawego serca niejasnego pochodzenia u 74-letniej chorej-im więcej szukamy, tym więcej widzimy. (Folia Cardiologica)

- Cukrzyca monogenowa MODY 2 - warto o niej pamiętać - opisy przypadków. (Endokrynologia Pediatryczna)

- Zanim rozpoznasz u pacjenta zaburzenie konwersyjne, doktadnie zbadaj jego stan somatyczny i neurologiczny. Opis przypadku. (Psychiatria Polska)

- Kontrowersje wokót rozpoznania tocznia rumieniowatego indukowanego lekami anty-TNF- $\alpha$ u pacjentki leczonej z powodu tuszczycy. (Przegląd Dermatologiczny)

Oprócz wyżej wymienionych informacji, tytuły medycznych opisów przypadków przekazują także inne dane, tj. informacje o klinice (r), objawach lub ich braku (s), przyczynę choroby $(\mathrm{t}) \mathrm{i}$ inne.

(r)

- Zakrzepica zatok żylnych mózgowia u dzieci - analiza przypadków klinicznych 5 dzieci hospitalizowanych $\boldsymbol{w}$ Klinice Neurologii Dziecięcej w Rzeszowie. (Neurologia Dziecięca)

(s)

- Bezobjawowy śluzak lewego przedsionka. (Folia Cardiologica)

- Zmiany paznokciowe jako glówna manifestacja liszaja lśniącego. (Przegląd Dermatologiczny)

- Wrzodziejace zapalenie jelita grubego u 2-letniego dziecka. (Pediatria Polska)

- Wytrzeszcz gatki ocznej jako pierwszy objaw rozsianej postaci raka drobnokomórkowego pluc. (Klinika Oczna)

(t)

- Dziedziczna neuropatia nerwu wzrokowego Lebera - opis dwóch przypadków. (Klinika Oczna)

- Zespót Kleefstra z wrodzona niedoczynnościa tarczycy u 4-letniej dziewczynki. (Endokrynologia Pediatryczna)

Warto przyjrzeć się również warstwie gramatycznej i leksykalnej tytułów. Zauważalne jest tu powszechne występowanie rzeczowników i przymiotników złożonych. Zastosowanie takiej grupy środków językowych nie tylko umożliwia sformułowanie 
dokładnego, nie pozostawiającego wątpliwości po stronie czytelnika, opisu lokalizacji choroby, objawów, metod leczenia itp., ale również wyrażenie go w porównywalnie krótszej formie niż przy użyciu fraz przyimkowych ze spójnikami.

- Późne powikłania sercowo-naczyniowe i oskrzelowo-plucne u chorej leczonej wysokimi dawkami radioterapii z powodu chtoniaka Hodgkina. (Kardiologia Polska)

- Żoladkowo-jelitowo-trzustkowy rak neuroendokrynny w postaci krwotocznej torbieli trzustki. (Gastroenterologia Polska)

- Zespót sromowo-pochwowo-dziąstowy - opis przypadku. (Przegląd Dermatologiczny)

- Obustronny otoczkowiak wspótistniejący synchronicznie z gruczolakotorbielakowlókniakiem surowiczym jajnika lewego - opis przypadku. (Ginekologia i Położnictwo)

Występują tu również liczne przymiotniki (w celu dokładności opisu; jak wyżej) określające lokalizację choroby, m.in. „obustronny”, „lewy”; stopień i rozmiar, np. „olbrzymi”, stadium choroby, np. ,wczesny” itp.

- $\quad$ Cystektomia z wytworzeniem zastepczego pęcherza jelitowego u pacjenta z ektopia nerki prawej. (Chirurgia Polska)

- Olbrzymi torbielakogruczolak śluzowy jajnika u 74-letniej pacjentki - opis przypadku. (Ginekologia i Położnictwo)

- Wczesna, bezobjawowa zakrzepica elektrody układu stymulującego skutecznie leczona zachowawczo. (Kardiologia Polska)

- Masywna hemoliza wewnatrznaczyniowa po interwencyjnym leczeniu ubytku w przegrodzie międzyprzedsionkowej. (Kardiologia Polska)

Przyglądając się warstwie terminologicznej, warto zauważyć, że w tytułach medycznych opisów przypadków występują często eponimy $(\mathrm{u})$, powstałe od odkrywców danej choroby oraz toponimy (w) (od miejsc/ nazw geograficznych). Występują tu także nieliczne nazwy, utworzone na drodze skojarzeń od zwierząt (x). Tendencje te uwarunkowane są jednak specyfiką języka medycznego, którego nieodłącznym elementem są nazwy eponimiczne i podobne, m.in.:

(u)

- Zespót Mayer-Rokitansky-Küster-Hauser jako przykład anomalii rozwojowych przewodów Müllera - opis różnych wariantów zespotu u pięciu dziewcząt. (Endokrynologia Pediatryczna)

- Zespót Ladda rozpoznany u 15-letniego chłopca - opis przypadku. (Pediatria Polska)

- Choroba Huntingtona zaburzeniem neurologicznym czy psychiatrycznym? Opis przypadku. (Psychiatria Polska)

- Rozległa choroba Bowena twarzy - leczenie skojarzone. (Przegląd Dermatologiczny)

(w) 
- $\quad$ Nawracajace zapalenie optucnej jako wiodacy objaw rodzinnej gorączki śródziemnomorskiej. (Pediatria Polska)

- $\quad$ Syndrom jerozolimski-opis przypadku. (Psychiatria Polska)

(x)

- Zespót pawiana ${ }^{8}$. Symetryczna, wyprzeniowa i zgięciowa osutka wywołana lekiem. (Przegląd Dermatologiczny)

Kolejnym elementem wartym uwagi są łączniki zdaniowe, które wprowadzają nowe pojęcia lub, jak sama nazwa wskazuje, łączą zdania. Najczęściej funkcję tę pełnią spójniki i przyimki.

- $\quad$ Asymetria stawu szczytowo-obrotowego jako jedna z ewentualnych przyczyn zawrotów głowy. (Otorynolaryngologia)

- Kwasica ketonowa a ,ostry brzuch” "w świeżo rozpoznanej cukrzycy typu 1 u dziecka - opis przypadku. (Endokrynologia Pediatryczna)

- $\quad$ Zespót Prader-Willi - diagnostyka i leczenie. (Endokrynologia Pediatryczna)

- 17-letnia pacjentka z choroba trzewna, autoimmunologicznym zapaleniem watroby i toczniem rumieniowatym uktadowym - opis przypadku. (Pediatria Polska)

- Dziewięcioletnie przeżycie ogólne w miejscowo zaawansowanej, nastęnie uogólnionej postaci niedrobnokomórkowego raka płuca. Opis przypadku. (Nowotwory)

- Afazja sensomotoryczna jako powikłanie zapalenia opon mózgowo-rdzeniowych i mózgu o etiologii Streptococcuspyogenes u 12-letniej dziewczynki. (Pediatria Polska)

Podobnie do badania F. Salager-Meyer, M. Ángeles Alcaraz Ariza i M.L. Briceño (2013) w niniejszym badaniu autorki przyjrzały się również znakom interpunkcyjnym. W wyżej wspomnianej pracy, w tytułach anglojęzycznych najczęściej występowały dwukropki, które wprowadzały nowe zagadnienia, wyjaśnienie, procedurę badawczą itd. Natomiast w tytułach polskich najczęściej występują myślniki, które z kolei wprowadzają frazę „,opis przypadku” lub inne wyjaśnienie; czasem funkcję taką pełni również dwukropek, rzadziej kropka. Zaobserwowano tu także cudzysłowy, określające pojęcia niespecjalistyczne lub łagodzące wypowiedź.

- $\quad$ Qutenza - Kapsaicyna 8\% plaster - terapia bólu neuropatycznego: opisy przypadków - własne obserwacje. (Anestezjologia i Ratownictwo)

- Infekcyjne zapalenie wsierdzia u chorego z wszczepionym układem stymulujacym skutecznie leczone antybiotykami: obserwacja dwuletnia. (Kardiologia Polska)

- Zespót pawiana. Symetryczna, wyprzeniowa i zgięciowa osutka wywołana lekiem. (Przegląd Dermatologiczny)

- Idiopatyczne, obustronne zapalenie błony naczyniowej-efektywność steroidoterapii ogólnej oraz iniekcji doszklistkowej dexamethazonu. Opis przypadku. (Klinika Oczna)

8 „Nazwa związana $\mathrm{z}$ podobieństwem zmian rumieniowych do wyglądu modzeli siedzeniowych u samic pawianów” (J. Maj; prezentacja multimedialna; dostęp: 27.03.2018). 
- „Ostry brzuch” u dziecka z ostra białaczka limfoblastyczna jako powikłanie chemioterapii indukcyjnej - opis przypadku. (Pediatria Polska)

Kończąc rozważania nad tytułami w polskojęzycznych opisach przypadków warto wspomnieć, iż autorki analizowały tylko niektóre aspekty gramatyczno-lingwistyczno-składniowe. Tworzy to pole do podjęcia dalszych badań w zakresie tendencji w tytułach, zarówno w języku polskim w zakresie medycyny, jak i w ujęciu komparatystycznym w innych językach/ czasopismach/ typach tekstów medycznych i innych.

\section{Uwagi końcowe}

Podsumowując rozważania nad polskojęzycznymi tytułami medycznych opisów przypadków, opublikowanych w latach 2012-2016, w porównaniu z badaniem F. Salager-Meyer, M. Ángeles Alcaraz Ariza i M.L. Briceño (2013), można sformułować następujące wnioski:

- Tytuły polskojęzyczne są nieznacznie dłuższe (11 słów) od tych w języku angielskim (9,7 słów) oraz porównywalne $\mathrm{z}$ artykułami naukowymi (10,9 słów) według badania Y. Wang/ Y. Bai (2007).

- Wszystkie analizowane tytuły miały charakter rzeczownikowy i tematyczny. W badanym korpusie nie pojawiały się tytuły czasownikowe, które występowały w opisach w języku angielskim, ale w polskich z kolei występowały różne konstrukcje zastępcze, np. imiesłowy. Pojawiały się także tytuły w formie pytania i te przyciągające uwagę (m.in. zawierające metafory).

- Tytuły w języku polskim przekazywały takie informacje jak: procedura badawcza, zastosowane leczenie i jego rezultat, opis narządu objętego chorobą, lokalizację, doprecyzowanie nazwy (ekwiwalenty obcojęzyczne, wyjaśnienia), przyczynę choroby itp.

- Analiza ilościowa wykazała, iż najczęściej występowały takie wyrażenia, przekazujące informację jak: „opis przypadku/ przypadków” i inne zamienniki (np. „studium przypadku” - głównie w psychologii; celem było określenie typu pracy; występowały w różnych miejscach) oraz ,przegląd piśmiennictwa" (jeden z etapów badania/ typ pracy).

- Pojawiały się tu także wyrazy odnoszące się do pacjenta oraz jego wieku, rzadkości zagadnienia, trudności diagnostycznych i terapeutycznych, obserwacje własne autorów itp.

- Rzadko występowały też różne inne wyrażenia, np. zalecenia w formie bezpośredniego zwrotu do czytelnika. Tytuły przekazują także informacje o klinice (jednostce medycznej), objawach choroby itp.

- Na płaszczyźnie gramatycznej zauważono zastosowanie rzeczowników i przymiotników złożonych w celu uzyskania dokładności opisu jak i krótszej formy, przymiotników do określenia lokalizacji, stadium choroby itp., łączników zdaniowych (głównie spójników i przyimków) oraz znaków interpunkcyjnych (myślniki, rzadziej dwukropki, kropki i cudzysłowy). 
- Pojawiały się również eponimy, toponimy oraz nazwy utworzone od zwierząt na drodze skojarzeń. Wynika to jednak ze specyfiki języka medycyny.

Głównym wnioskiem płynącym z powyższych rozważań jest to, iż tytuły medycznych opisów przypadków w języku polskim (niniejsze badanie) i angielskim (prace F. Salager-Meyer i M. Ángeles Alcaraz Ariza 2013a, b oraz F. Salager-Meyer, M. Ángeles Alcaraz Ariza i M.L. Briceño 2013), mają podobne cechy na płaszczyźnie gramatycznej, leksykalnej i strukturalnej, a nieznaczne różnice spowodowane są przez specyfikę danego języka.

\section{Bibliografia}

Agha, R.A. i in. (2016), The SCARE Statement: Consensus-based Surgical Case Report Guidelines, (w:) International Journal of Surgery 34, 180-186.

An, X.J./ R.Z. Zhang (1994), Translating Chinese Titles of Medical Papers into English, (w:) Foreign Medical Sciences 15 (4), 179-181.

Baicchi, A. (2003), Relation Complexity of Titles and Texts: A Semiotic Taxonomy, (w:) L. Merlini Barbaresi (red.), Complexity in Language and Text. Pisa, 319341.

Brkic, S./ M. Vucenovic/ Z. Dokic (2003), Title, Abstract, Key Words and References in Biomedical Articles, (w:) Archive of Oncology 11 (3), 207-209.

Budgell, B. (2008), Guidelines to the writing of case studies, (w:) Journal of Canadian Chiropractic Association 52(4), 199-204.

Busch-Lauer, I. (2000), Titles in English and German Research Papers in Medicine and Linguistics, (w:) A. Trosborg (red.), Analysing Professional Genres. Amsterdam, 77-97.

Duan, P./ W.P. Gu (2002), Common Errors in the Translation of Titles and Abstracts of Medical Papers, (w:) Chinese Translation Journal 23 (4), 17.

Gasparyan, A.Y. i in. (2011), Writing a Narrative Biomedical Review: Considerations for Authors, Peer Reviewers, and Editors, (w:) Rheumatology International 31, $1409-1417$.

Goodman, N.W. (2000), Survey of Active Verbs in the Titles of Clinical Trials Reports, (w:) British Medical Journal 320, 914-915.

Goodman, R.A./ S.B. Thacker/ P.Z. Siegel (2001), What's in a Title? A Descriptive Study of Article Titles in Peer-Reviewed Medical Journals, (w:) Science Editor 24(3), 75-78.

Halliday, M.A.K. (1970), Language Structure and Language Function, (w:) J. Lyons (red.), New Horizons in Linguistics. Harmondsworth, 140-165.

Hartley, J. (2005), To Attract or to Inform: What Are Titles for?, (w:) Journal of Technical Writing and Communication 35 (2), 203-213.

Hartley, J. (2007a), There's More to the Title than Meets the Eye: Exploring the Possibilities, (w:) Journal of Technical Writing and Communication 37 (1), 95-101.

Hartley, J. (2007b), Colonic Titles!, (w:) The Write Stuff 16 (4), 147-149. 
Hartley, J./ L. Betts (2007), The Effects of Spacing and Titles on Judgments of the Effectiveness of Structured Abstracts, (w:) Journal of the American Society for Information Science and Technology 58 (14), 2335-2340.

Hays, J.C. (2010), Eight Recommendations for Writing Titles of Scientific Manuscripts, (w:) Public Health Nursing 27, 2, 101-103.

Jacques, S.J./ N.J. Sebire (2010), The Impact of Article Titles on Citation Hits: An Analysis of General and Specialist Medical Journals, (w:) Journal of the Royal Society of Medicine 1 (1), 2.

Jiang, J.Q. (2000), Writing Medical Paper Titles in English, (w:) Journal of Chengdu Military Command Hospital 2 (4), 50-51.

Kotur, P.F. (2002), How to Write Scientific Article for a Journal?, (w:) Indian Journal of Anesthesiology 46 (1), 21-25.

Leng, H.M./ J.X. Guo (2003), Translating Chinese Titles of Medical Papers into English, (w:) Journal of Regional Anatomy and Operative Surgery 12 (2), 140-141.

Lewison G./ J. Hartley (2005), What's in a Title? Numbers of Words and the Presence of Colons, (w:) Scientometrics 63, 341-356.

Ma, J.W./ X.W. Wang (1997), Structural Characteristics of English Titles of Medical Papers, (w:) Journal of Med. Intel. 17 (4), 16-18.

Mack, C. (2001), How to Write a Good Scientific Paper: Title, Abstract, and Keywords, (w:) Micro/Nanolithography, MEMS, and MOEMS 11, 2.

Maj, J., Systemowe kontaktowe zapalenie skóry. Prezentacja multimedialna. (dostęp: 27.03.2018; https://www.termedia.pl/f/f/ef0bb16b00101a6e043ece7a5b1df392.pdf).

Ortega-Loubon, C./ R. Correa-Márquez (2014), Writing a Case Report: A Work of Art, (w:) International Journal of Medical Students 2 (3), 90-91.

Pereira, K.R. (2016), A Physician's Guide to the World of Medical Publications, (w:) Annals of Tropical Medicine and Public Health 9 (6), 392-395.

Rison, R.A./ M.R. Kidd/ C.A. Koch (2013), The CARE (CAse REport) Guidelines and the Standardization of Case Reports, (w:) Journal of Medical Case Reports 7, 261.

Rosner, R.A. (1990), Reflections on Science as a Product, (w:) Nature 345, 108.

Salager-Meyer, F./ M. Ángeles Alcaraz Ariza (2013a), Titles are "Serious Stuff: A Historical Study of Academic Titles, (w:) JAHR 4 (7), 257-272.

Salager-Meyer, F./ M. Ángeles Alcaraz Ariza (2013b), The Medical Narrative from a Diachronic Perspective (1840-2009): Titling Practices and Authorship, (w:) M. Gotti/ C. Sancha Guinda (red.), Narratives in Academic and Professional Genres. Bern, 293-318.

Salager-Meyer, F./ M. Ángeles Alcaraz Ariza/ M.L. Briceño (2013), Titling and Authorship Practice in Medical Case Reports: A Diachronic Study (1840-2009), (w:) Communication and Medicine 10 (1), 63-80.

Siegel, P.Z. et al. (2006), Titles of Articles in Peer-reviewed Journals Lack Information on Study Design: A Structured Review of Contributions to Four Leading Medical Journals, 1995 and 2001, (w:) Science Editor 29 (6), 183-185.

Smith, R. (2000), Informative Titles in the BMJ, (w:) British Medical Journal 320, 914. 
Soler, V. (2007), Writing Titles in Science: An Exploratory Study, (w:) English for Specific Purposes 26 (1), 90-102.

Soler, V. (2011), Comparative and Contrastive Observations on Scientific Titles in Written English and Spanish, (w:) English for Specific Purposes 30, 124-137.

Swales, J. (1990), Genre Analysis. English in Academic and Research Settings. Cambridge.

Wang, Y./ Y. Bai. (2007), A Corpus-based Syntactic Study of Medical Research Article Titles, (w:) System 35, 388-399.

Williams, J.M. (2009), Style: The Basics of Clarity and Grace (3rd edn.) New York.

Xu, Y.Z. (1996), Writing English Titles of Medical Papers, (w:) Journal of Datong Medical College 16 (1), 59-63.

Xue, Z.L. (2003), Writing English Abstracts of Medical Papers (I): Titles. Foreign Medical Sciences, (w:) Sec. Pathophysiol. Clin. Med 23 (4), 439-441.

Yao, S.L./ D.W. Wu/ S.H. Zhang (2004), Familiar Sentences in the Title and Abstract of Medical Papers in English, (w:) Lishizhen Medicine and Materia Medica Research 15 (5), 319.

Zeiger M. (1991), Essentials of Writing Biomedical Research Papers. New York. 